\title{
Assessment of drinking water quality in Kamalanagar, Lawngtlai district, Mizoram
}

\author{
John Blick \\ Department of Geology, Mizoram University, Tanhril 796004, Mizoram, India \\ Corresponding author: johnblick0316@gmail.com
}

\begin{abstract}
The selected study area belongs to southwest part of Mizoram constituting north-east India. The whole region is in limelight due to its presence of considerable toxic element contamination in different water sources including neighboring states of Assam, Manipur, Tripura and also Bangladesh. Drinking water is highly polluted with different harmful contaminants due to Increase human population, use of fertilizers, pesticides, manures, anthropogenic activities etc. For mankind, knowledge of water quality is vital and is directly linked with human warfare. Hence, it seems essential to explore different water sources of remote areas where people are totally dependent on alternative potable sources largely viz. sub surface and groundwater. The present study focused to establish the current status of physico-chemical characteristics in order to determine its suitability for drinking and other household purposes in accordance to the standards prescribed by World Health Organisation (WHO) and Bureau of Indian Standards (BIS). Therefore, tuikhurs (sub-surface) and hand pumps samples at different sites were collected and analyzed as per standard methods. The physico-chemical parameters like pH, electrical conductivity (EC), total dissolved solids (TDS), total hardness (TH), total chlorides (TCL), iron and free chlorine are well within the acceptable limits and is thus fittable for drinking water. However, concentration of arsenic and turbidity is slightly higher than the permissible limits but still within the acceptance limit of $0.05 \mathrm{mg} / \mathrm{l}$ and 5 nephelo turbidity unit (NTU) respectively.
\end{abstract}

Keywords: Toxic metals, standard levels, water parameters, rock-water interaction.

\section{INTRODUCTION}

One of the most important and abundant compounds is water, which is essential for all living organisms for their growth and survival. For drinking, irrigation, industrial and household purposes, groundwater is the most important source next to sub-surface water. Globally, drinking water quality has been declining abruptly particularly in developing countries, due to natural and anthropogenic processes (Carpenter, 1998; Chen, 2002). Recent development in various fields such as agriculture, industry, factory and urbanization have led to increase in the demand of water supply which are met mostly from exploitation of groundwater resources. The surface and sub-surface water in fact get time to interact with the rocks, soils, organisms and all possible means on the earth as well as below the earth surface. As a result, the water becomes good enough with inclusion of requisite minerals required and good for health to human beings. In this process, sometimes water is also being recipient of some toxic content in form of heavy metals such as cadmium, arsenic, nickel, etc. Presence of arsenic as major toxic components in groundwater has been established in the neighboring states of Assam, Tripura, Manipur and also in Bangladesh. However, it is first time reporting of arsenic from the territory of Mizoram from the localities bordering Tripura and Bangladesh.

Our drinking water today, far from being pure, contains some two hundred deadly commercial chemicals. Therefore, the demand of fresh water has to be fulfilled from its indigenous resources. Agricultural activities in the past decade have shown presence of toxic biochemical, pesticides and insecticides for agricultural productivity. This has led to the problem of arsenic contamination, endosulfan and various water borne diseases. Hence, a 


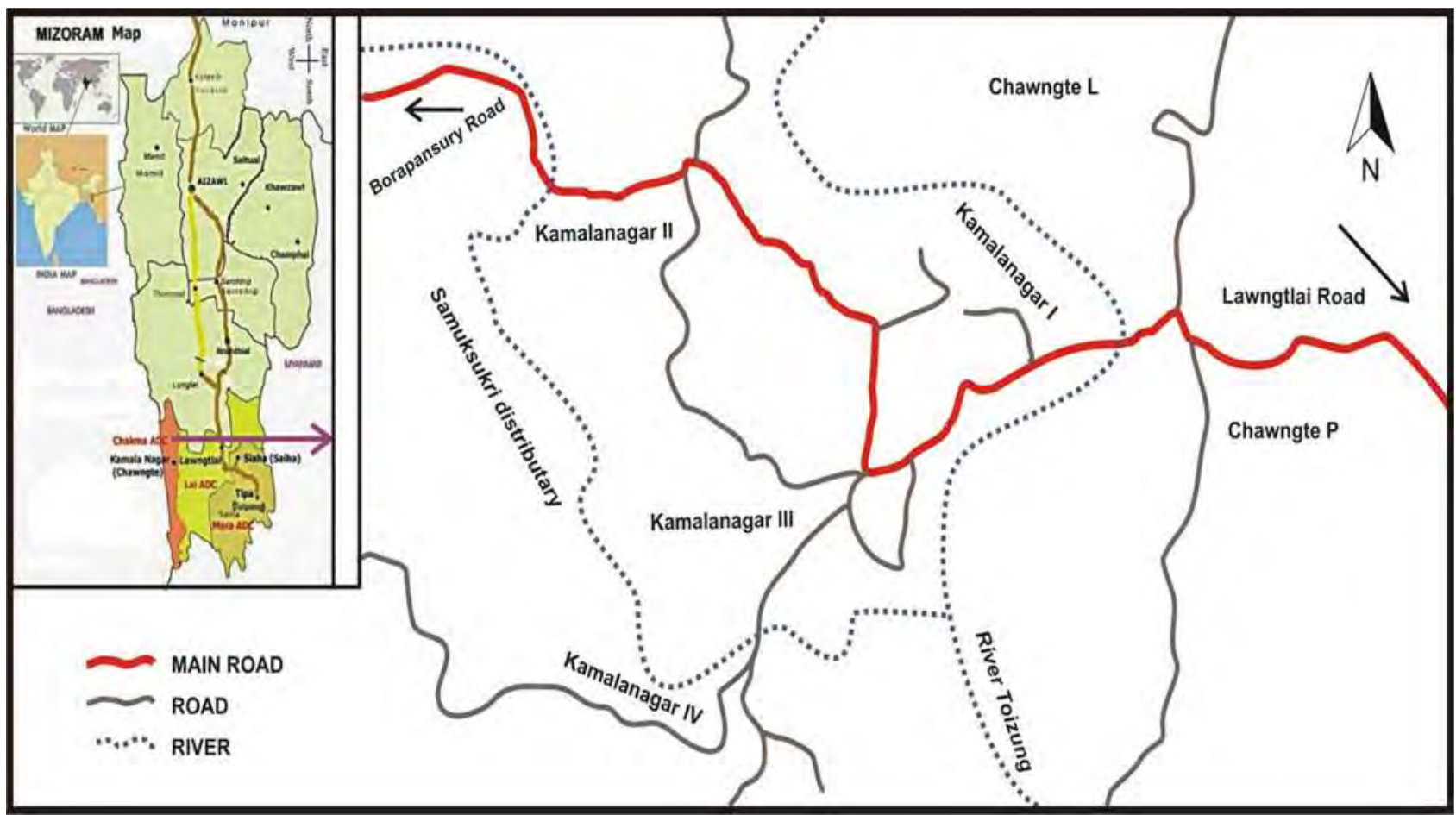

Figure 1: Location map of the study area.

township at remote location in Mizoram has been selected for present study which is situated at neighboring of Bangladesh.

\section{Materials AND MethodS}

The study area Kamalanagar Chawngte block lies in the western parts of Lawngtlai district and is located at $22^{\circ} 37^{\prime} 10^{\prime \prime} \mathrm{N}$ and $92^{\circ} 38^{\prime} 11^{\prime \prime} \mathrm{E}$ (Figure 1). It is situated on international border with Bangladesh and having a distance of $34 \mathrm{~km}$ towards west from district headquarters Lawngtlai. Under these circumstances, it seems mandatory to explore various potable sources in the state for their suitability to potable water standards established by Bureau of Indian Standards (BIS) and World Health Organization (WHO). The objectives of the present work are to establish physico-chemical characterization of all possible potable water sources and to demarcate water sources which are not within recommendation of BIS and WHO in order to optimize the health condition of the resident of the study area.

The samples were collected in the pre- monsoon season from the selected sites and have been taken for detailed hydrological and hydro geochemical investigations. Samples from three different water sources have been coded as; sub-surface water (tuikhur)= SW, groundwater (dug well) $=$ DW and groundwater (hand pump) $=$ HP. Out of ten samples, four samples are from sub-surface water, three samples are from dug well and three samples are from hand pumps. Sampling was performed according to the recommendations of the American Public Health
Association (APHA), American Water Works Association (AWWA) and Water Environment Research Foundation (WEF). Various sources of potable water were identified during the survey of study area. Water samples were collected in a wide mouth bottle (Tarsons bottle), washed with distilled water and again rinsed with representative water samples. Water samples were analyzed in situ to find out the physico-chemical properties like $\mathrm{pH}$, turbidity, total dissolved solids (TDS), electrical conductivity (EC), total hardness (TH), total chlorides (TC), total iron $(\mathrm{Fe})$, free chlorine $\left(\mathrm{FCl}_{2}\right)$, nitrate $\left(\mathrm{NO}_{3}\right)$ and arsenic (As). Digital instruments made by Eutech instruments were used to test $\mathrm{pH}$, TDS and $\mathrm{EC}$. TH, TCl, Fe, $\mathrm{TCl}_{2}$ and $\mathrm{NO}_{3}$ were measured using the water testing kit made by Transchem Agritech Limited. Arsenic concentration was measured using an arsenic test kit made by Merckoquant Chemicals, Germany. Turbidity values of the samples were measured using the Digital Nephelo Turbidity Meter-132 (systronics) using formazine as standard.

\section{RESUlT AND DISCUSSION}

The physical and chemical properties analysis results of all potable sources in the study area are showed and presented in the Table 1 and 2 respectively. Electrical conductivity varies from a minimum of $110 \mu \mathrm{S} / \mathrm{cm}$ to a maximum $220 \mu \mathrm{S} / \mathrm{cm}$ (Figure 2). The EC values are generally higher for tuikhur water in comparison to the hand pump. Conductivity can be regarded as a crude indicator of water quality for many purposes, since it is related to the sum of all ionized solutes or total dissolved solid con- 


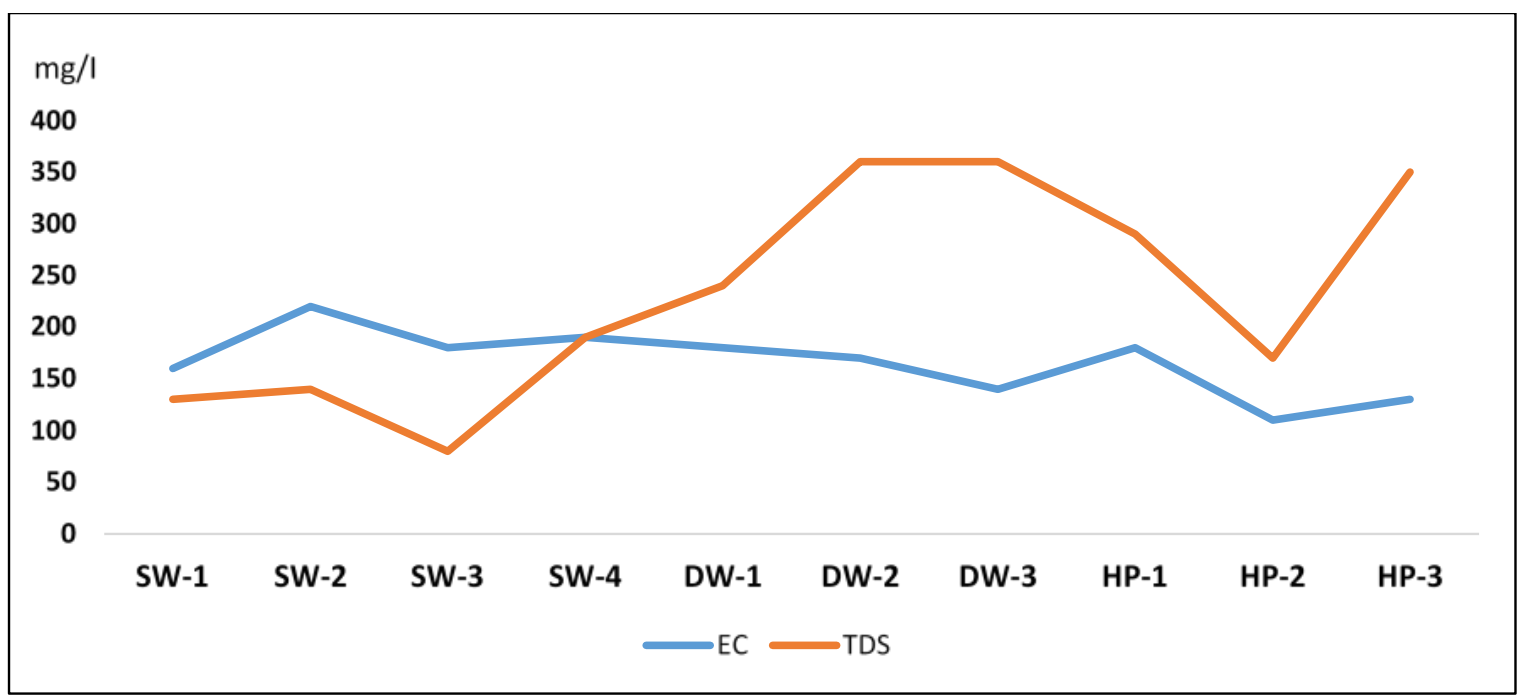

Figure 2: Plot of electrical conductivity vs total dissolved solids.

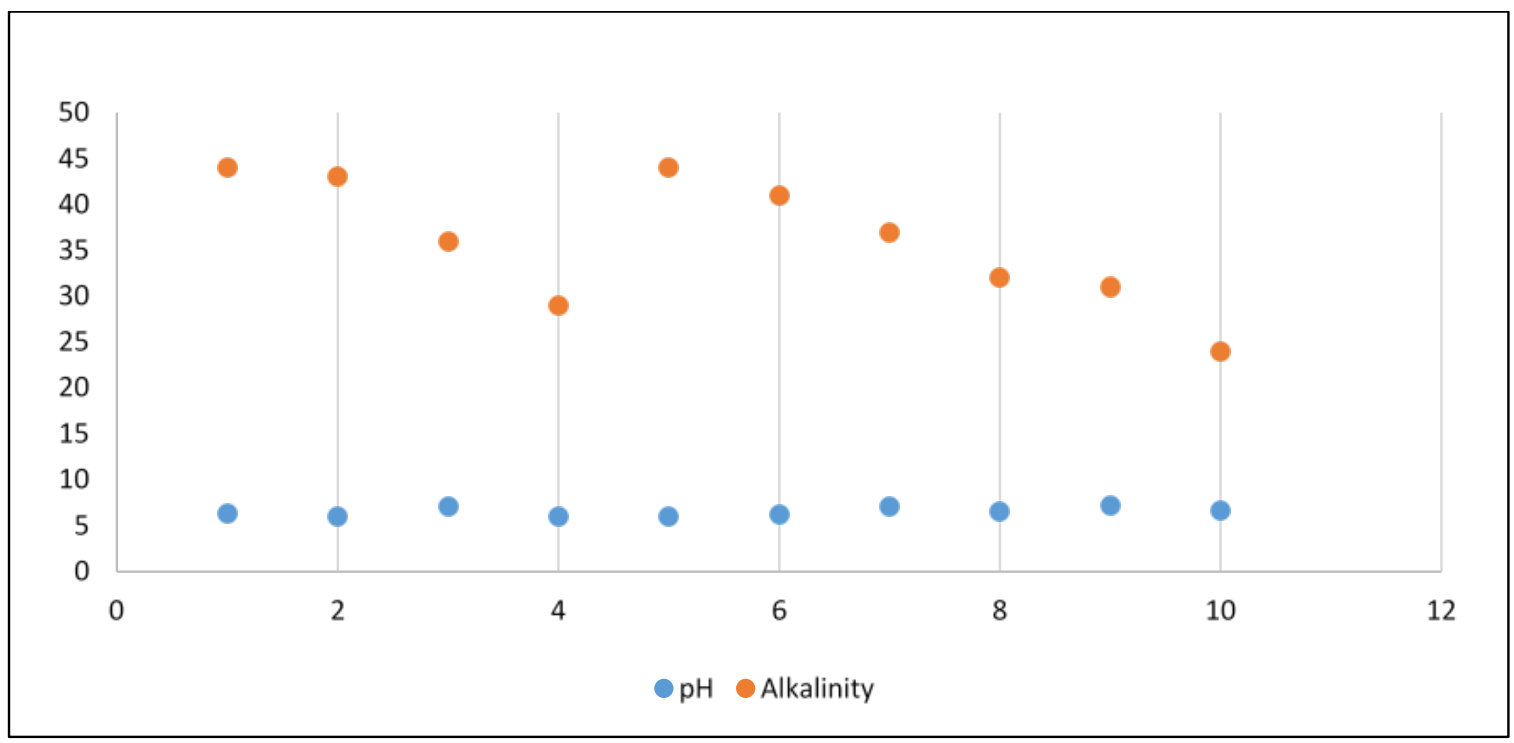

Figure 3: Plot of $\mathrm{pH}$ vs alkalinity.

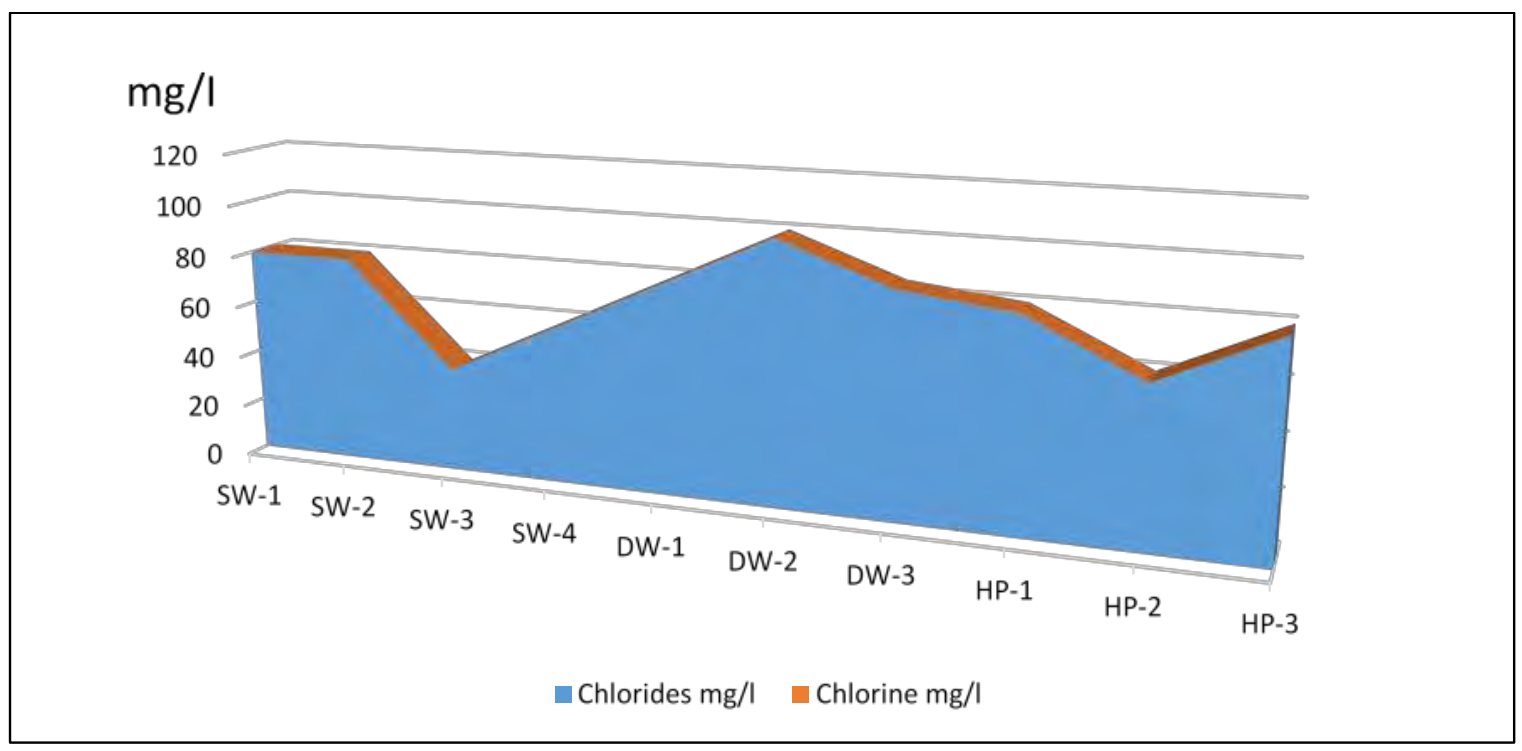

Figure 4: Plot of total chlorides vs total chlorine. 
Table 1: Water analyses results (physical parameters).

\begin{tabular}{|l|l|c|c|c|c|c|}
\hline Code & Location & pH & EC & TDS & Turbidity & Alkalinity \\
\hline SW-1 & Kamalanagar-S & 6.4 & 160 & 130 & 4 & 44 \\
\hline SW-2 & Kamalanagar-I & 6.0 & 220 & 140 & 5 & 43 \\
\hline SW-3 & Kamalanagar-N & 7.1 & 180 & 80 & 5 & 36 \\
\hline SW-4 & Santinagar Village & 6.0 & 190 & 190 & 4 & 29 \\
\hline DW-1 & Kamalanagar-W & 6.0 & 180 & 240 & 3 & 44 \\
\hline DW-2 & Kamalanagar-II & 6.2 & 170 & 360 & 4 & 41 \\
\hline DW-3 & Kamalanagar-III & 7.1 & 140 & 360 & 5 & 37 \\
\hline HP-1 & Kamalanagar-II & 6.5 & 180 & 290 & 5 & 32 \\
\hline HP-2 & Kamalanagar-I & 7.2 & 110 & 170 & 3 & 31 \\
\hline HP-3 & Kamalanagar-IV & 6.7 & 130 & 350 & 4 & 24 \\
\hline & WHO Permissible limits & $6.5-8.5$ & 600 & 500 & -- & 200 \\
\hline & BIS Permissible limits & $6.5-8.5$ & 2000 & 2000 & 5 & 200 \\
\hline
\end{tabular}

Table 2: Water analyses results (chemical parameters).

\begin{tabular}{||l||l||c||c||c||c||c||c||}
\hline \hline \multicolumn{1}{|c|}{ Code } & Location & TH & TCl & $\mathbf{T C l}_{2}$ & Fe & NO & As \\
\hline \hline SW-1 & Kamalanagar-S & 105 & 80 & 0.3 & 0.1 & Trace & 0.03 \\
\hline \hline SW-2 & Kamalanagar-I & 90 & 80 & 0.2 & Trace & Trace & 0.02 \\
\hline \hline SW-3 & Kamalanagar-N & 90 & 40 & 0.2 & 0.1 & Trace & 0.01 \\
\hline \hline SW-4 & Santinagar Village & 110 & 60 & 0.1 & 0.2 & Trace & 0.05 \\
\hline \hline DW-1 & Kamalanagar-W & 105 & 80 & 0.2 & Trace & Trace & 0.05 \\
\hline \hline DW-2 & Kamalanagar-II & 60 & 100 & 0.2 & 0.1 & Trace & 0.03 \\
\hline \hline DW-3 & Kamalanagar-III & 75 & 85 & 0.1 & 0.2 & Trace & 0.02 \\
\hline \hline HP-1 & Kamalanagar-II & 90 & 80 & 0.3 & 0.5 & Trace & 0.01 \\
\hline \hline HP-2 & Kamalanagar-I & 75 & 60 & 0.1 & 2 & Trace & 0.02 \\
\hline \hline HP-3 & Kamalanagar-IV & 90 & 80 & 0.2 & 3 & Trace & 0.01 \\
\hline \hline & WHO Permissible limits & 500 & 200 & -- & 0.1 & 50 & 0.05 \\
\hline \hline & BIS Permissible limits & 600 & 1000 & 1.0 & 0.3 & 45 & 0.05 \\
\hline
\end{tabular}

tent. The TDS varies from a minimum of $80 \mathrm{mg} / \mathrm{l}$ to a maximum of $360 \mathrm{mg} / \mathrm{l}$. Higher values of TDS may be attributed mainly to geochemical rock-water intercalation in the area, which adds a number of electrolytes to the water bodies (Gupta et al., 2008). The desirable limit of TDS in drinking water is $500 \mathrm{mg} / \mathrm{l}$. It can be seen that the $\mathrm{pH}$ varies from 6.0-7.2, which are found to be well within the acceptance limit for drinking water (6.5-8.5) as specified by the BIS and WHO (Figure 3). Depending on $\mathrm{pH}$ and alkalinity, hardness above about $200 \mathrm{mg} / \mathrm{l}$ can result in scale deposition, particularly on heating. Soft waters with a hardness of less than about $100 \mathrm{mg} / \mathrm{l}$ have a low buffering capacity and may be more corrosive (WHO, 2003). For turbidity, it is observed that all the values of the stations have slightly higher than the desirable limit but still within the permissible limit of 5 NTU.

The total hardness varies from 60 to $110 \mathrm{mg} / \mathrm{l}$. Its desirable limit is $200 \mathrm{mg} / \mathrm{l}$ and permissible limit is 600 $\mathrm{mg} / \mathrm{l}$. The amount of free chlorine present in various stations varies from $0.1-0.3 \mathrm{mg} / \mathrm{l}$. Low values of free chlorine are obtained in SW-4, DW-3 and HP-2, high values are in SW-1 and HP-1 (Figure 4). However, the values are found to be well within the desirable limit. The free chlo- rine, which is the chlorine available to inactivate diseasecausing organisms, and is thus a measure used to determine the potability of water. The concentration of chloride in all the stations - SW, DW and HP samples are much lower (40-100 $\mathrm{mg} / \mathrm{l})$ than the desirable limits value of $250 \mathrm{mg} / \mathrm{l}$ prescribed by BIS as well as WHO. Chloride concentration above $250 \mathrm{mg} / \mathrm{l}$ can produce a distinct taste in drinking water. Where chloride content is known to be low, a noticeable increase in chloride concentrations may indicate pollution from sewage sources.

The low concentration of nitrate in all the stations is mainly due to less use of nitrogenous fertilizers as it is derived mostly from residual chemical fertilizers applied to agricultural land to increase productivity (Basu et al., 2007; Kumar et al., 2010). The total iron content for various stations varies from trace to $3 \mathrm{mg} / \mathrm{l}$. The Environmental Protection Agency (EPA) considers iron as a secondary contaminant, which means it does not have a direct impact on health. The Secondary Maximum Contaminant Level set out by the EPA is $0.3 \mathrm{mg} / \mathrm{l}$, but this is merely a guideline and not a federal standard. Typically, around $15 \mathrm{mg} / \mathrm{l}$, Idaho's well water does contain quite high amounts of iron, but the level is still not enough to 
cause physical harm (Colter, 2006). Arsenic compounds are found in rock, soil, water and air as well as in plant and animal tissues.

Drinking water can be contaminated with inorganic arsenic by either through wind-blown dust in mining areas, leaching of or Run off from soil, dissolution of rocks, minerals and ores during rock-water interaction. The amount of arsenic concentration of $0.01 \mathrm{mg} /$ (permissible limit) is obtained in three stations, viz. SW-3, HP-1 and HP-3, while SW-4 and DW-1 concentration of arsenic is exceeding the permissible limit obtaining a value of $0.05 \mathrm{mg} / \mathrm{l}$. Chakraborti et al. (2004) and Nickson et al. (2005) have reported that most of the arsenic affected floodplains in Asia are by the side of the rivers that originate in the Himalayas or Tibet Plateau. Thus it is considered that Himalayas and surrounding mountains are potential sources of arsenic bearing minerals. Because the north-eastern hill states of India are part of the Himalayan mountain range, it is anticipated that contamination of arsenic in groundwater may present in the Newer Alluvium (Holocene) of the Surma.

\section{Conclusion}

The physico-chemical parameters like $\mathrm{pH}$, electrical conductivity, total dissolved solids, total hardness, total chlorides, iron and free chlorine are well within the acceptable limits for drinking water. However, arsenic and turbidity are slightly higher than the permissible limits but still within the acceptance limit of $0.05 \mathrm{mg} / \mathrm{l}$ and 5 NTU respectively. From the above parameters, all the tuikhurs, hand pumps and dug wells are fit to serve as water source for domestic purposes.

\section{REFERENCES}

APHA, AWWA, WEF (2005). Standard Methods for the Examination of Water and Waste Water Analysis $20^{\text {th }}$ Edition. American Public Health Association, Washington, DC.
Basu, K.N., Padmalal, D., Maya, K., Sareeja, R., Aurn, P.R. (2007). Quality of surface and groundwater around tile and brick clay mines in Chalakudy river basin, southwestern India. Geological Society of India, 69, 279-284.

BIS (2012). Specification for Drinking Water. Bureau of Indian Standards ISO: 10500, New Delhi.

Blick, J., Kumar, S. (2017). Assessment of potable water quality of surface water (tuikhur) and hand pumps in Siaha, southern Mizoram. Science Vision, 17 (3), 163171.

Blick, J., Kumar, S., Lalruatfeli, M., Verma, R. (2018). Quality analysis of selected drinking water of Kolasib district, northern Mizoram (India). Genius, 6 (2), 149159.

Chakraborti, D., Sengupta, M.K., Rahman, M.M., et al. (2004). Groundwater arsenic contamination and its health effects in the Ganga-Meghna-Brahmaputra plain. Environmental Monitoring and Assessment, 6, 74-83.

Colter, A., Mahler, R.L. (2006). Iron in drinking water. Pacific Northwest Journal, 589, 1-2.

Gupta, S., Mahato, A., Roy, P., Datta, J.K., Saha, R.N. (2008). Geochemistry of groundwater Burdwan District, West Bengal, India. Environmental Geology, 53, 1271-1282.

Kumar, S., Bharti, V.K., Singh, K.B., Singh, T.N. (2010). Quality assessment of potable water in the town of Kolasib, Mizoram (India). Environmental Earth Sciences, 61, 115-121.

Nickson, R., McArthur, J.M., Shrestha, B., Kyawmyint, T.O., Lowry, D. (2005). Arsenic and other drinking water quality issues, Muzaffargarh District, Pakistan. Applied Geochemistry, 20, 55-68.

WHO (2003). Hardness in drinking-water. Background document for preparation of WHO Guidelines for drinking-water quality. WHO, Geneva. 